\title{
Parents' Perception: Early Childhood Social Behaviour During Physical Distancing in the Covid-19 Pandemic
}

\author{
Luluk Ekyana ${ }^{1}$ \\ Mohammad Fauziddin ${ }^{2}$ \\ Nurul Arifiyanti ${ }^{3}$ \\ Universitas IVET Semarang ${ }^{1}$, Indonesia \\ Universitas Pahlawan Tuanku Tambusai ${ }^{2}$, Indonesia \\ Sekolah Tinggi Agama Islam NU Purworejo ${ }^{3}$, Indonesia
}

DOI: https://doi.org/10.21009/JPUD.152.04

Accepted: September $15^{\text {th }}$ 2021.Approved: October $4^{\text {th }} 2021$. Published: November $30^{\text {th }}, 2021$

\begin{abstract}
During physical distancing, children do not meet their peers to play or talk together. Peer relationships have a crucial influence on all child development, especially for social skills or behaviour during early childhood. This study aims to determine changes in children's social behaviour during physical distancing during the Covid-19 pandemic. This research method is a descriptive quantitative study designed with the percentage value was used as a score for measuring the results of parental observations of children concerning the child's social behaviour instrument. Quota sampling (150 parents) was used to reach participants from various cities in Indonesia to see cultural differences. Data on children's social behaviour was obtained using the Preschool and Kindergarten Behaviour Scale (PKBS) tests. The data were then analysed using descriptive statistics. The results show that there are changes in children's social behaviour during physical distancing. Children who are less independent (58.9\%) are the biggest decline in social behaviour reported by parents, while the one who changes the least is cleaning up the mess that has been made (38.7\%). The implication of the results of this study is that parents should continue to pay attention to their children's social behaviour by providing opportunities for children to interact with peers in the house while still paying attention to health protocols.
\end{abstract}

Keywords: Early Childhood, Social Behaviour, Physical Distancing

\footnotetext{
${ }^{1}$ Corresponding Author:

Universitas IVET Semarang $^{1}$

Email: lulukelyana76@gmail.com
} 


\section{INTRODUCTION}

Physical distancing is an effective way to control the spread of the virus (Koh et al., 2020). Research conducted in New South Wales found that there was a decrease in physical activity after the government-imposed physical distancing (Munasinghe et al., 2020). Not only adults, but children also experience a decrease in activity. Half of the 345 children in one study reported that they rarely played in parks and public playgrounds during the pandemic (McCormack et al., 2020). Parents who are worried about this pandemic prefer their children to play in front of the computer or games rather than outdoors, because there has been a change from what was "outdoor play mode" to "indoor play mode" (de Figueiredo et al., 2021).

Online learning has become a new habit in the education system in Indonesia. This learning program certainly makes it easier for teachers and students. Children do not need to come to school in the morning, so they can save costs (Arkorful \& Abaidoo, 2015). However, parents stated that the implementation of online learning during the pandemic was always problematic and full of challenges (Dong et al., 2020). Most teachers and managers of kindergarten institutions also reported having difficulty implementing it (Munastiwi \& Puryono, 2021).

Online learning also affects a child's social life because this situation reduces the child's ability to see other people and turns it into a virtual meeting (Popyk, 2020). Children cannot meet their peers to play or tell stories together. Therefore, this situation must receive attention and support from parents considering the crucial influence of peer relations on all aspects of child development (Sendil \& Erden, 2012). Furthermore, it can also have an impact on children's behaviour or social competence during early childhood, which has a strong relationship with behavioural problems, especially in preschool (Corredor et al., 2017). In learning children need to interact with other people directly to build aspects of social development that are difficult if done virtually or online. These interactions are used for playing drama, storytelling, collaborating with friends, and based on projects so that children's social skills can be formed (Aksoy \& Baran, 2010). In a study, it was stated that a good child-teacher relationship in the first three months of school can predict children's social skills at the end of the year (Zhang \& Nurmi, 2012). This condition is feared bad for social development because children who have consistent daily routines are reported to have better social skills and show fewer behavioural problems (Ren \& Xu, 2019).

Previous research has focused more on the psychological effects of physical distancing such as research by Liu et al., 2021; Munasinghe et al., 2020; McCormack et al., 2020; Lau \& Lee, 2020; and Morgül et al., 2020, but not much has been discussed about children's social behaviour during physical distancing. The impact of physical standing on children's social skills needs to be studied further to minimize the formation of an individualistic attitude and do not care about others. Therefore, this study aims to find out how parents view their children's social behaviour during the pandemic. 


\section{THEORITICAL STUDY}

\subsection{Children's Social Skills}

Social skills are children's skills to interact, build relationships, and stay away from social behaviour that others don't like (Goodman et al., 2015). This behaviour is also shown by frequent communication, empathy, affection, friendliness, and easy to cooperation. Children who have good social skills are never alone, shy, or withdrawn from society. They also have self-control thanks to habituation and direction from their environment. This refers to the child's ability to manage and express his emotions when faced with something that may not be in accordance with his wishes and thoughts. The child accepts or refuses by showing certain behaviours such as anger or smiling. Further social skills include the ability to be active in the game, sportsmanship, lead, see the strengths of friends not as obstacles, make quick decisions, confident, work together, communicate well, like to try and never give up, and easy to make friends (Sintia et al., 2019).

Furthermore, social skills also affect the independence of kindergarten age children (Rusmayadi \& Herman, 2019). Children can interact with other people using expected behaviour when they have good social skills management. This affects attitudes and behaviour when doing activities or playing so that independence will be formed. Independence is a person's ability to not be too dependent on the presence of others. Independent early childhood reflects an attitude that can perform daily life skills without the help of adults. For example, an independent child will try to feed himself, take off his socks without help, and choose clothes that he likes. The higher a child's social skills, the easier it is for him to make friends with other people around him. Furthermore, social skills allow children to acquire new thoughts obtained by discussing and observing the behaviour around them. They will show more initiative than other friends and can decide what interests them without being influenced by adults.

Previous research has shown that early childhood social skills can be stimulated through games (Sari et al., 2019). Through these activities, children can learn to cooperate with others, learn to appreciate, and want to share. Furthermore, other studies also report that children's interactions with peers in a game have an impact on their social abilities (Ramadhani \& Fauziah, 2020). They learn how to behave to be accepted by their friends in the group. In this case, children's thoughts and emotions play a role so that they can adjust to the demands of their group. When playing, children can give each other advice, exchange opinions, understand other people's emotions, and find solutions to problems they face together. Even in the preschool period, peer relationships improve and can predict children's social development in later ages. Playing drama, storytelling, outbound activities, and project-based learning is some of the educational activities that can stimulate social skills (Aksoy \& Baran, 2010; Izza, 2020; Sintia et al., 2019). All these activities must involve other people to be able to complete each task or challenge given. The relationships that exist in some of these activities help pre-schoolers understand the 
feelings of others. Children will learn that there are other people who have a different perspective from themselves, namely their playmates (Setyawan et al., 2021).

Unfortunately, the COVID-19 pandemic keeps children at home and reduces activities that involve interaction with their peers. This condition increases the risk of children's social skills being low and if left unchecked can give birth to an individualist generation. Studies reveal that peers can help children obey rules, help them learn new things, and teach sharing (Melinda \& Izzati, 2014). The presence of peers in a child's life can have a major impact on various aspects of his development. Especially for emotional social development, will learn to imitate what their peers do. Strong motivation arises from within the child when he sees his peer's sharing, working together to make a building with blocks, and calming when a friend cries because he falls. Change will occur when the child who previously quite became more open to telling stories when he joins peers. Children who lacked confidence will change to have the belief that they can do it because of the support they get from their friends.

\subsection{The Role of Parents on Children's Social Skills}

Family, school, mass media, and society are agents of socialization. Early childhood can learn how to behave well, understand other people's feelings, and manage their emotions (Berns, 2007). Behavioural learning is done by making what is done by the surrounding environment as a model for example in behaviour. To support children's social skills during the COVID-19 pandemic, parents must provide feelings of love, supervision, set an example, and teach to do well to others (Kusuma et al., 2022). Furthermore, parents act as the environment that forms the first social behaviour in children. They can provide various story books with exemplary values, participate in playing with children, guide children to get used to doing homework, and control when children play with gadgets. They can invite children to discuss how to develop cooperative attitudes, help each other, share attitudes, speak politely, adapt. Help children have self-identity to express their desires, how to socialize, negotiate, and solve problems when conflicts occur (Setyawan et al., 2021).

The role of parents in developing children's social skill is as first educators and as friends for children (Siregar \& Subiyantoro, 2021). Parents teach children to be polite, responsible, and prosocial to others by empathizing, sharing, and respecting the opinions of others. Meanwhile, as friends for children, parents consider children as individuals who are always learning. They are willing to be friends and a comfortable place for children to tell stories. Positive encouragement and always optimistic about children's abilities are important to raise children's confidence. When there is a problem, it is not the parent who takes control but helps the child to solve the problem. Therefore, higher supportive parenting is associated with improving children's social skills and reducing the presence of problem behaviours (Ren et al., 2019; Wang et al., 2021).

In order for children's social skills to develop well, parents need to collaborate with teachers (Rachman \& Cahyani, 2019). These two parties are agents who are heavily 
involved in the lives and changes of children's attitudes. Any information obtained from teachers through communication media provided by schools such as WhatsApp and contact books needs to be followed up by parents. They can work together to find the best solution to deal with inappropriate or problematic child behaviour. The continuous response between school and home makes it easier for children to understand the responsibilities and consequences of each attitude that he shows.

\subsection{Changes in Children's Daily Routines During Physical Distancing}

The pandemic has reduced the process of face-to-face interaction. Children should keep their distance from other people, including their peers to prevent the spread of the virus. The Indonesian government has implemented physical distancing since February 2020. All schools must be closed, and students learn online from home. Families with early childhood have to face unprecedented situations and lead a new life (Morelli et al., 2020). On the other hand, the rule to stay at home during the pandemic has changed the parents' view of early childhood education, which always prioritizes free play outdoors (Stephen \& Edwards, 2018). Even so, parents still choose to let their children play outside so they can play with their friends (Munasinghe et al., 2020). They believe that activities like this have tremendous benefits for children's development. This view is also reinforced by kindergarten teachers in rural schools who usually spend a minimum of two hours per day doing outdoor activities in favourable weather conditions. They stated that outdoor activities encouraged children to play in groups rather than playing indoors, which can affect children's social development.

Daily routine is one of the important aspects in child development. During the pandemic, the use of digital screens was the most common activity for children (CachónZagalaz et al., 2021). They must be in front of a computer screen to study online and look for activities to fill their spare time during physical distancing. Playing games and watching videos from YouTube are chosen by children to fill their spare time. Previous research reported that around $71.7 \%$ of 1115 parents stated that screen time in children increased during the COVID-19 pandemic (Ozturk Eyimaya \& Yalçin Irmak, 2021). Follow-up observations showed that children who were away from their social life, school, and hobbies during physical distancing spent more time in front of the gadget screen after the online learning system was implemented.

The duration of gadget use is related to the socio-emotional development of children (Setiawati et al., 2019). Research shows that most children who have a habit of playing gadgets for more than one hour every day have a decline in social development (Chaelin, 2018). Children who often use gadgets are more apathetic to the environment. The level of aggression will also increase. Therefore, they do not need other people to play, and this must always be watched by parents considering there are negative effects from using gadgets, especially for children's social-emotional development.

Never meeting peers and only socializing with a few people are dangerous for social skills and relationships. A study showed $59.6 \%$ of respondents believed social relations 
had weakened during this situation, more than $30 \%$ believed family relations had become strained, while $47.8 \%$ said the lock down had made them very bored (Naser et al., 2020). Furthermore, people suffer from isolation from friends and the community (AlTammemi, 2020; Brooks et al., 2020) even though friends have a significant role in children's prosocial behaviour because they always give evaluations (Diesendruck \& BenEliyahu, 2006) and a positive social climate (Leeuw et al., 2019). Suggestions from other friends let child know how to adjust behaviour to be accepted by others. Therefore, friends have an important role in changing the views of children's behaviour when playing together.

\section{METHOD}

This research method is a descriptive quantitative study designed (Gay et al., 2012)to explore various perceptions that parents have about their children's social behaviour during the pandemic. The researcher collected data with the survey method, and the percentage value was used as a score for measuring the results of parental observations of children concerning the child's social behaviour instrument. This method was chosen because the data acquisition can describe the high and low social behaviour of children during physical distancing. Data on changes in children's social behaviour is based on the views of parents who during the Covid-19 pandemic accompanied their children, nurtured, and educated their children at home. This is because parents are the closest parties to children who know and memorize their child's behaviour before and after physical distancing. On the other hand, data collection based on parents' views is also because behaviour is not something that is easy to observe. Observation of behaviour takes a long time to produce consistent data. Therefore, a data source is needed that can provide information on changes in children's behaviour with the criteria of interacting with children every day.

Due to the physical distancing period, the researchers conducted an online survey using Google Form on February 15 - 26, 2021. The researcher shared information about the needs of participants through WhatsApp groups to everyone who has a boy or girl aged 3-6 years. Using a quota sampling strategy, this study tries to reach participants from various cities in Indonesia to see cultural differences. We prepared 150 quotas, but only 124 participants filled out the questionnaire. Information regarding the research objectives is available on the invitation and research instruments. The data used in this study involved 124 parents (father $n=29,23.4 \%$; mother $n=96,77.4 \%$ ). They were aged between 20-50 years, and half were aged 31-40 years (53.22\%). As shown in Table 1, most of the participants were from Java Island $(n=90)$, had a permanent job $(n=83$, $67 \%)$, have not completed higher education $(\mathrm{n}=72,58.0 \%)$, have children aged six years $(\mathrm{n}=42,33.9 \%)$, have daughters $(\mathrm{n}=68,54.8 \%)$, and have enrolled children in educational programs early childhood $(\mathrm{n}=101,81.5 \%)$.

Table 1. Sociodemographic of Parents

Parent

http://journal.unj.ac.id/unj/index.php/jpud 263 


\begin{tabular}{|c|c|c|}
\hline Father & 29 & 23.4 \\
\hline Mother & 96 & 77.4 \\
\hline \multicolumn{3}{|l|}{ Age } \\
\hline $20-25$ & 4 & 3.2 \\
\hline $26-30$ & 26 & 26 \\
\hline $31-35$ & 36 & 29 \\
\hline $36-40$ & 30 & 24.2 \\
\hline $41-45$ & 21 & 16.9 \\
\hline $46-50$ & 8 & 6.5 \\
\hline \multicolumn{3}{|l|}{ Domicile } \\
\hline Sumatera & 20 & 16.1 \\
\hline Jawa & 89 & 71.7 \\
\hline Kalimantan & 2 & 1.6 \\
\hline Bali & 13 & 10.4 \\
\hline \multicolumn{3}{|l|}{ Job status } \\
\hline Private & 28 & 22.6 \\
\hline Working steadily & 55 & 44.4 \\
\hline Does not work & 41 & 33.1 \\
\hline \multicolumn{3}{|l|}{ Educational status } \\
\hline Primary school & 2 & 1.6 \\
\hline junior high school & 11 & 8.9 \\
\hline senior High School & 59 & 47.6 \\
\hline Bachelor & 43 & 34.7 \\
\hline Postgraduate & 9 & 7.3 \\
\hline \multicolumn{3}{|l|}{ Child's age } \\
\hline 3 years & 27 & 21.8 \\
\hline 4 years & 29 & 23.4 \\
\hline 5 years & 28 & 22.6 \\
\hline 6 years & 42 & 33.9 \\
\hline \multicolumn{3}{|l|}{ Child Gender } \\
\hline Male & 57 & 46 \\
\hline Female & 68 & 54.8 \\
\hline \multicolumn{3}{|c|}{ Enrolled in an ECE institution } \\
\hline Yes & 101 & 81.5 \\
\hline No & 23 & 18.5 \\
\hline
\end{tabular}

\subsection{Instrument}

The child's social behaviour questionnaire was adopted from the Preschool and Kindergarten Behaviour Scale Test (PKBS Test) (Merell, 2013). The process of adopting the instrument is done by not changing the existing items or indicators of social behaviour. The Preschool and Kindergarten Behaviour Scale Test (PKBS Test) have two sub tests, to measure social skills and problem behaviour. However, the researcher only used one subtest, social skills because it was in accordance with the data to be obtained. Social behaviour indicators consist of: (1) social cooperation (cooperation, following rules, selfcontrol, sitting and listening to others who are talking, sharing, giving, being responsible, and responding). (2) Social interaction (understanding others, participating, asking for help, comforting others, and giving forgiveness). (3) social independence (playing independently, smiling with others, being accepted by others, and trying new tasks). 
These indicators have five scales $(1=$ less than before quarantine; $5=$ more often than before quarantine (Morgül et al., 2020). With a different scale, this study tries to assess children's social behaviour before and during physical distancing.

\subsection{Data Analysis}

After the process of filling out the questionnaire was closed, the incoming data was then analysed by indicators according to the research instrument that the researcher adopted. Descriptive statistics (means and frequencies) were used to analyse the socio demographics of parents and children's social skills. Social behaviour is said to change if parents fill in very less or less, while it does not change if parents fill in often or more often. To make conclusions easier, the data entered on each social behaviour scale is converted into percentages.

\section{RESULT AND DISCUSSION}

\subsection{Result}

The results showed that almost half of the parents who participated saw a change in their child's social behaviour. Children become less independent (58.9\%), cooperative (58.9\%), smiling and laughing with other children (42.7\%). P laying with several different friends $(50.8 \%)$, self-controls (45.2\%), being invited by other friends to play (60.4\%), use time usefully (39.5\%), invite other friends to play (46.0\%), and clean up the mess that has been made (38.7\%) (see Table 2). Meanwhile, almost half, or more parents reported some behaviours remained the same or did not change even though the children rarely interacted with other people were trying to defend the rights belonged to him, being able to separate from parents to carry out an activity without pressure, being liked or others, others, friends. others, understand the conditions that occur with their friends, accept easily and decisions given by adults, and return objects or toys taken to their original places.

Furthermore, the results of this study indicate that there are social behaviours that are often carried out by children because of the presence of parents. A total of $39.5 \%$ of parents reported that their children asked for their help when they were in trouble, and $45.1 \%$ sought comfort from their parents when they were sad. Family members working from home appear to be a favourable situation for some children because they can bond and channel their emotions. On the other hand, $60.5 \%$ of parents stated that their children still understand the rules even though they are not at school. This may be related to the results of other social behaviour scales, namely that parents provide opportunities for children to express their opinions when discussing. Children also sit and listen when a piece of advice is told. Therefore, the rules made by parents at home seem more acceptable to children. Finally, the only social behaviour that remains the same or does not change is defending the rights that belong to the child $(49.3 \%)$.

Table 2. Parents' Views on Changes in Children's Social Behaviour Before and After Physical Distancing 


\begin{tabular}{|c|c|c|c|c|c|}
\hline Social Behavior Scale & $\begin{array}{l}\text { Very } \\
\text { reduced } \\
n(\%)\end{array}$ & $\begin{array}{l}\text { Reduced } \\
n(\%)\end{array}$ & $\begin{array}{l}\text { Same } \\
n(\%)\end{array}$ & $\begin{array}{l}\text { Often } \\
n(\%)\end{array}$ & $\begin{array}{l}\text { More } \\
\text { Often } \\
n(\%)\end{array}$ \\
\hline $\begin{array}{l}\text { Independent when playing or doing an } \\
\text { activity }\end{array}$ & 26.6 & 32.3 & 21 & 15.3 & 4.8 \\
\hline Collaborating with other people & 25.8 & 33.1 & 22.6 & 16.1 & 4 \\
\hline Smiling and laughing with other children & 12.9 & 29.8 & 41.9 & 8.9 & 7.3 \\
\hline $\begin{array}{l}\text { Play with friends who have differences both } \\
\text { physically, religiously, ethnically, and } \\
\text { nationally }\end{array}$ & 21.8 & 29 & 41.9 & 4 & 3.2 \\
\hline $\begin{array}{l}\text { Understand the conditions that occur with } \\
\text { his friends }\end{array}$ & 8.9 & 26.6 & 44.4 & 12.9 & 7.3 \\
\hline liked or accepted by other friends & 8.9 & 21 & 53.2 & 8.1 & 9.7 \\
\hline Following adult advice or orders & 9.7 & 19.4 & 38.7 & 23.4 & 9.7 \\
\hline $\begin{array}{l}\text { Trying his best to do an activity before he } \\
\text { asks an adult for help }\end{array}$ & 8.1 & 18.5 & 40.3 & 21.8 & 12.1 \\
\hline Make friends easily & 12.1 & 25 & 43.5 & 10.5 & 8.9 \\
\hline Show self-control & 8.9 & 36.3 & 36.3 & 14.5 & 6.5 \\
\hline Invited by other friends to play together & 16.9 & 43.5 & 24.2 & 9.7 & 5.6 \\
\hline Use free time for useful activities & 5.6 & 33.9 & 34.7 & 22.6 & 3.2 \\
\hline $\begin{array}{l}\text { Separate from parents to do an activity } \\
\text { without pressure }\end{array}$ & 9.7 & 22.6 & 45.2 & 17.7 & 4.8 \\
\hline Opinions when invited to activities & 5.6 & 16.9 & 41.9 & 23.4 & 12.1 \\
\hline Ask an adult for help when you need it & 4 & 16.1 & 40.3 & 26.6 & 12.9 \\
\hline $\begin{array}{l}\text { Sit back and listen when telling a story or } \\
\text { advice }\end{array}$ & 4.8 & 24.2 & 38.7 & 19.4 & 12.9 \\
\hline Stand up to defend the rights of his friends & 5.6 & 27.4 & 40.3 & 18.5 & 8.1 \\
\hline Easy to adapt to new environment & 13.7 & 22.6 & 41.9 & 12.1 & 10.5 \\
\hline $\begin{array}{l}\text { Have special / special abilities that other } \\
\text { friends idolize }\end{array}$ & 7.3 & 20.2 & 41.9 & 21 & 9.7 \\
\hline Invite other friends to play together & 14.5 & 31.5 & 34.7 & 10.5 & 8.9 \\
\hline The problem itself & 9.7 & 36 & 35.5 & 19.4 & 6.5 \\
\hline Orderly rules & 8.9 & 30.6 & 40.3 & 16.1 & 6.5 \\
\hline Seek comfort from adults when sad & 5.6 & 13.7 & 36.3 & 29 & 16.1 \\
\hline
\end{tabular}

\subsubsection{Changes in Behaviour in terms of the Child's Gender}

Analysis of the results of the study also focused on gender differences in children. Of the 33 social behaviour scales, we only emphasize the behaviour reported by half of the total number of participants. The result is that parents with daughters reported more decreased social behaviour of independence $(n=31.5 \%)$, cooperation $(n=51.4 \%)$, playing with several different friends $(\mathrm{n}=29.8 \%)$, being invited by other friends to play $(21.8 \%)$, and use time usefully (21.8\%) (see Figure 1).

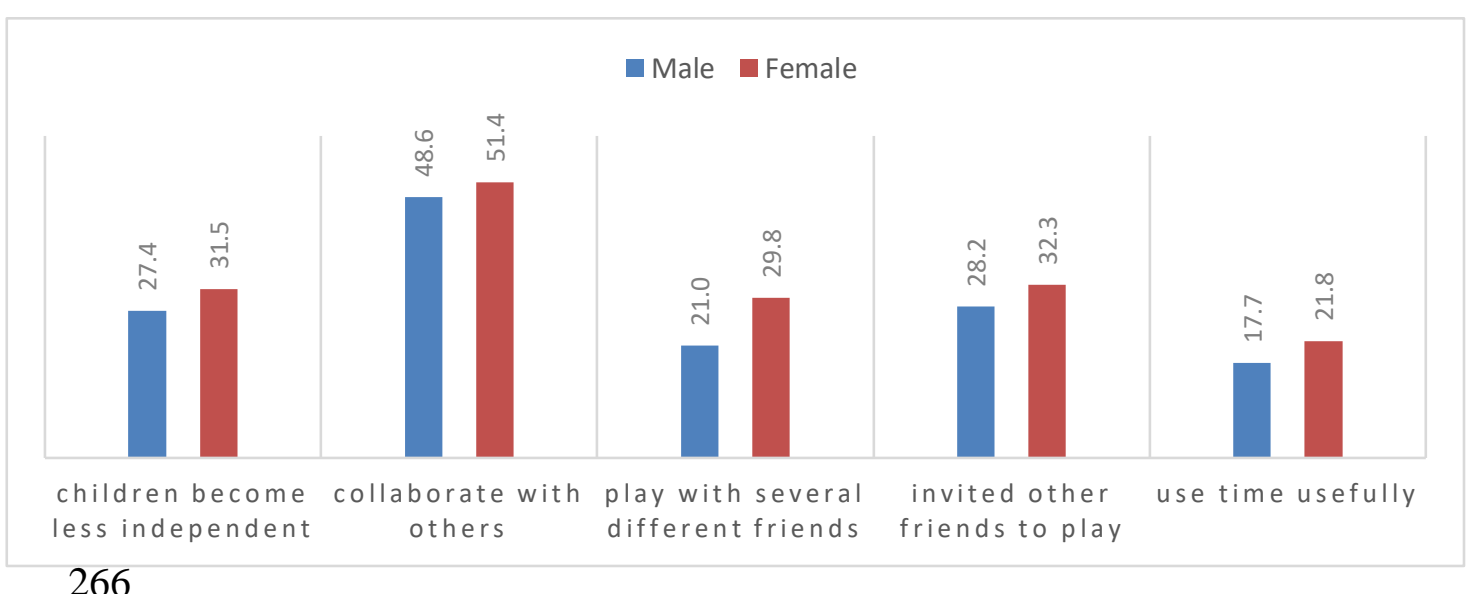


Figure 1. Graph of Differences in Changes in Decreased Social Behaviour in terms of Gender

\subsubsection{Changes In Reduced Social Behaviour in Terms of Children's Age}

The participants who were the subjects in this study were parents who had children aged three to six years. Analysis of the data showed that the reduction in social behaviour was most experienced by various age groups. Decreased instrument points (independent behaviour, cooperation with others, and playing with several different friends) were reported the most by parents of six-year-old children. The decrease in instrument points (behaviour of being invited by other friends to play) was reported the most by parents of three-year-old children. Decreased instrument points (useful use of time behaviour) were reported the most by parents of five-year-old children (see Figure 2).

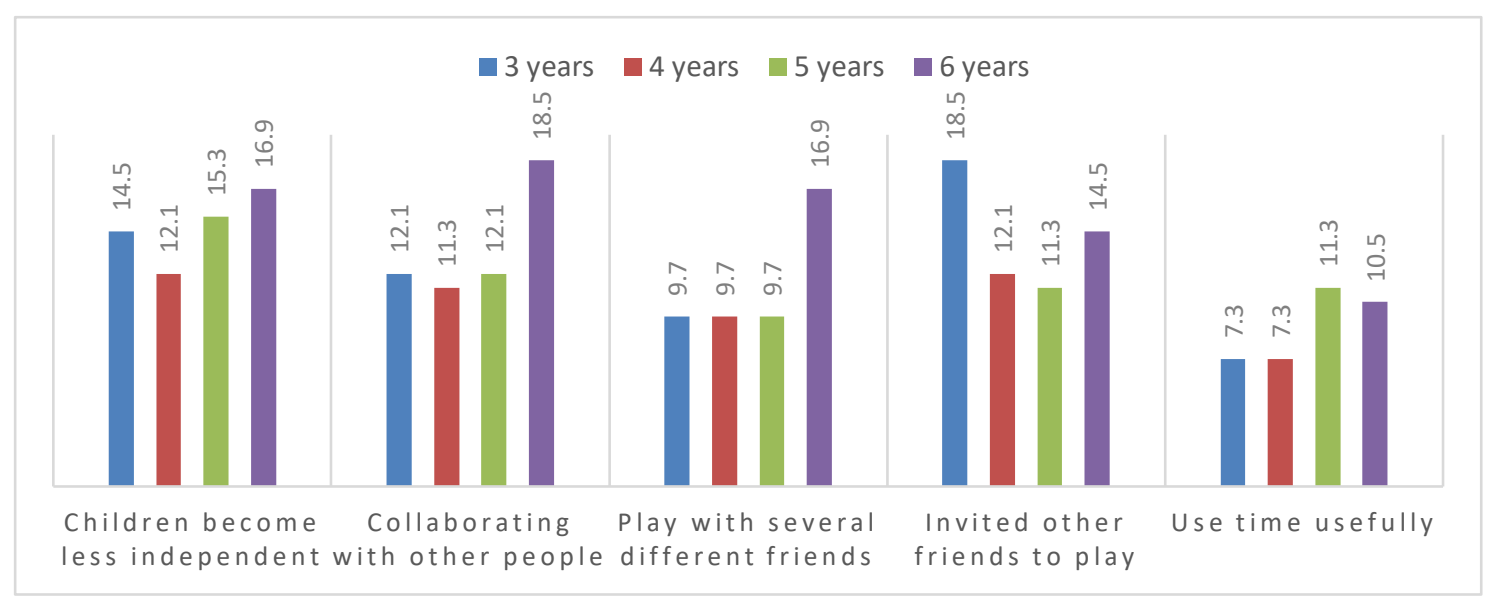

Figure 2. Graph of Differences in Changes in Decreased Social Behaviour in terms of Children's Age

\subsubsection{Changes In Reduced Social Behaviour in Terms of Parents' Employment Status}

The occupational demographics of the parents who were participants in our study had different job, starting civil housewives, servants, entrepreneurs, teachers, and lecturers. However, to simplify the data analysis process, we grouped the various types of work into three categories, parents who have private jobs, permanent jobs, and those who do not work. Most of the reduced changes in social behaviour were reported by parents who have permanent jobs as teachers, civil servants, lecturers, police officers, and employees (see figure 3).

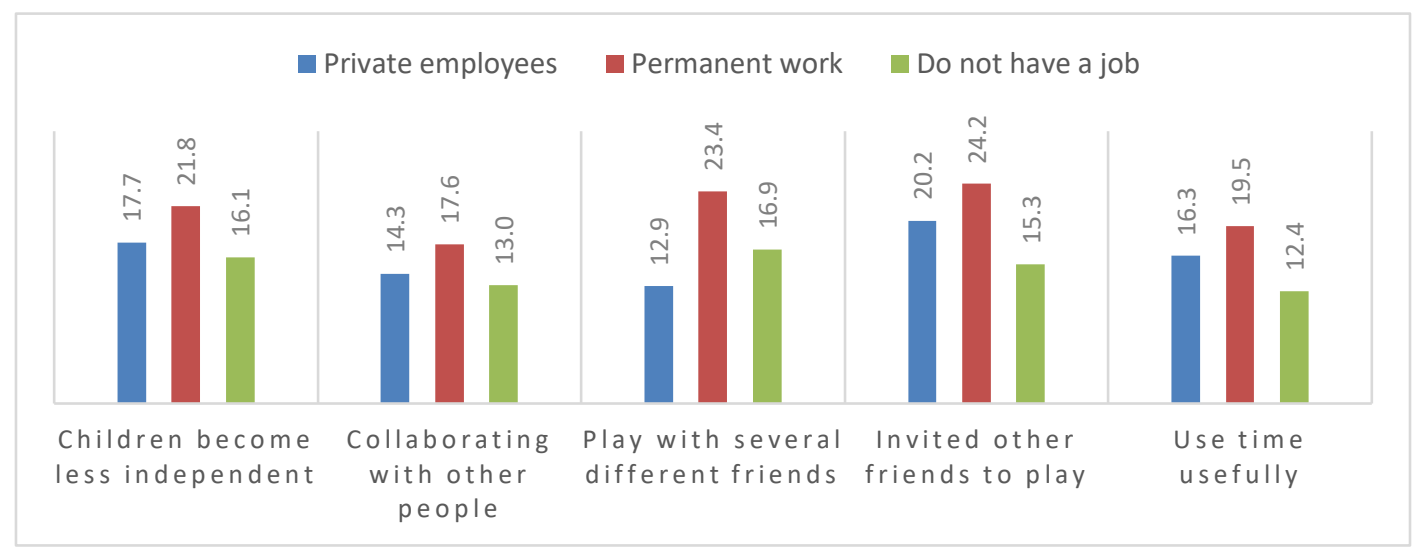


Figure 3. Graph of Differences in Changes in Decreased Social Behaviour in terms of Parents' Employment Status

\subsection{Discussion}

This study tries to find out the views of parents on changes in children's social behaviour before and during physical distancing in several cities in Indonesia using an online survey. Parents' views on children's behaviour during a pandemic are more challenging and stressful than ever (Tchimtchoua Tamo, 2020). The findings showed that parents noticed a change in their child's social behaviour before and after physical distancing. This result is in line with previous studies that reported that parents found their children's behaviour changed, such as being anti-social during the Covid-19 pandemic (Gelir \& Duzen, 2021). They observed children sitting more and spending time in front of the monitor screen. Children rarely engage in physical activity and have inconsistent waking and going to bed schedules. Even an introverted attitude begins to grow in them so that parents rarely understand what their children want.

A study revealed that actually early childhood was not very interested in socializing online (Mantovani et al., 2021). They are also less involved in learning that involves children's emotional social stimulation. Schools during the pandemic give more assignments related to academics, so parents must accompany their children throughout the learning process. It is not easy for teachers to find the right learning methods and resources for online learning. The lack of preparation for distance learning and teaching and the low training required for online teaching pose challenges for teachers when implementing online learning, especially for the stimulation of aspects of social skills (Atiles et al., 2021).

The decrease in the level of independence of children is one of the most reported by half the total number of parents. This is in line with research showing that many children are unable to complete tasks independently during a pandemic (Lau \& Lee, 2020). Parents also noticed a decrease in social behaviour related to playing and cooperation. This is because many people have limitations to social contact, large gatherings, and gatherings during the pandemic (Baloran, 2020). They must stay away from public places to reduce the transmission of COVID-19. This is reported to have made many children feel anxious. Furthermore, this condition hinders children's rights, especially to play and participate (Kyriazis et al., 2020). Physical distancing does not allow children to play with their peers. However, teachers can provide a program of activities that involve family members to play together at home (O'Keeffe \& McNally, 2021). Thus, the stimulation of children's social behaviour can still be done even though the learning is carried out remotely.

Although a study shows that as physical distancing increases children's interaction and communication with parents and sibling (Ceylan et al., 2021), children who have social adjustment problems may not be able to form peer relationships due to lack of adaptation 
training at home (Gülay \& Önder, 2013). For example, parents with high technology interference cause children to have low emotional control and poor prosocial behaviour (Merkaš et al., 2021). Therefore, it is important for parents and teachers to continue to monitor children's socio-emotional development during the pandemic so that negative risks can be controlled.

Another important finding was that parents reported that there was a decrease in the behaviour of children who were rarely invited or invited other children to play together. Socially, children miss their peers (Idoiaga Mondragon et al., 2021) during physical distancing. They become sad and want to cry even though their family is always there. This is in accordance with the results of observations in this study where children reported rarely smiling and laughing with other children. Playing with friends and schoolmates are some of the activities that children want so that they don't get tired of feeling alone. Children wish they had more time with friends, more play time, and outdoor activities (Pascal \& Bertram, 2021). Play helps children to connect feelings, ideas, and real experiences. Although schools have facilitated virtual meetings with their friends, interaction between children remains limited (Hu et al., 2020). The quality is also not as good as if met in person. Although it is included in the category of active screen time because stimulation and response can occur repeatedly, virtual meetings cannot support optimal stimulation of children's social skills development. Meeting virtually is qualitatively different from face-to-face interaction, and early childhood does not learn well socially through these media. This may be different if applied to adults.

Physical distancing cause's children to suffer because their social relationships with peers are disrupted. Playing with peers and going to kindergarten was reported to be the activity most missed by children (Mantovani et al., 2021). These two things are something that parents are afraid of in the future because of the lack of children interacting with the community. They don't understand what social behaviour is expected because everyone is busy keeping their distance. Even some parents in the study were also reported to have begun to find signs of a slow decline in children's social development.

Parents also report that their child's self-control is reduced. Previous research has shown that the mother's choice of punishment to discipline her child is reported to have influenced the development of self-control in children (Nofziger, 2008). Mothers who have low self-control significantly affect the child's low self-control. Furthermore, ineffective parenting also affects children's self-control and aggressive behaviour (Unnever et al., 2006). Parents who must work in the office during the pandemic can cause their children to not be properly supervised while at home. Coupled with feeling tired coming home from work or losing work, parents feel more depressed and even lose control of themselves. On the other hand, this condition causes parents to use verbal violence (raising their voice, prohibiting, and punishing) their children (Parczewska, 2020) so they should have high self-control. However, for parents who work from home, it was also reported in a study that these conditions changed the daily activities they had been doing (e.g. waking up early, breakfast time, and bedtime) (Zhang, 2021). This 
situation may have a negative impact on changes in the child's self-control. Parents free their children to do what they like because of the burden conditions. Children's selfcontrol is also influenced by co-parenting that applies habituation consistently (Ren \& $\mathrm{Xu}, 2019)$.

The result of further research is that almost half of parents do not see any change in their children's behaviour to defend the rights that are theirs. Early childhood does not understand about rights. However, they are taught indirectly by the environment when interacting with other people. The three rights identified by previous studies in preschool children are equal ownership, influence, and value (Quennerstedt, 2016). The fulfilment of children's rights while at home is certainly inseparable from parenting. If parents try to provide opportunities for children, then their right to express their emotions will be fulfilled properly.

On the other hand, the researchers also found that in terms of gender, the decrease in social behaviour such as independence, cooperation, playing with several different friends, being invited by other friends, and using time usefully were more reported by parents who have daughters. The learning from the home program during the pandemic has reduced the social support that children receive. Previous studies have reported that the social support needed by girls is different from that of boys (Grier \& Boutakidis, 2018; Mohamed, 2017). Boys need parental support, while girls need teacher and parental support at the same time. This could be one of the contributing factors why the decline in social behaviour is more reported by parents with daughters. A good relationship between teachers and parents is an important process for the development of children. The ongoing relationship between the two during the transition from preschool to first grade is predicted to increase social skills and decrease problem behaviour (Sheridan et al., 2021). Understanding how children build relationships and behave towards others is necessary to support children's future success.

Although meetings with teachers are conducted virtually, the quality of attachment that is built is different from face-to-face meetings. During the ongoing pandemic, some teachers also experienced various pressures from health, safety, finance, education, and work. This condition causes teachers to focus less on planning and implementing online learning programs. The teacher's emotional feelings reduce his interest in interacting and the teacher's sensitivity to children's needs (Siekkinen et al., 2014). As a result, the material that children learn is emphasized on the knowledge aspect but minimal on the attitude aspect. The results of the study on the decline in social behaviour in terms of gender do not mean that it can be interpreted that there are differences between social behaviour between boys and girls, further studies are needed to identify them.

When viewed from the age of the child, it was parents with children aged six years that reported the most decreased behaviour, reduced independence behaviour, cooperation with others, and playing with several different friends. Based on child development standards, the age of six should have become more independent, have the initiative to choose or take decisions, and prefer to interact with their peers. This data contradicts 
previous studies, which state that girls show better social skills than boys. Parenting style can be one of the causes. A study reported that an authoritarian parenting style increased feelings of stress in children (Mochida et al., 2021). Meanwhile, children aged six years are in a transitional age from kindergarten to elementary school. They should have mastered various basic skills and life skills. Authoritarian parents always dictate to children to do what they want with the aim of the child's own future. They ask children to learn to read, write, count, choose according to parental directions, and do not give children the opportunity to do what they choose. Before the pandemic, it was easy for sixyear-olds to learn because there was continuity from school to home and vice versa. However, because the home study program causes the learning process to be carried out only by one party.

\subsection{Limitation}

This study has methodological shortcomings. Because most of the participants have a permanent job that affects their daily income, the generalization of the results of the study needs to be re-examined carefully, or it can be said that the generalization of this study only applies to the population in this study. Changes in children's social behaviour are based on parents' perceptions and not on observations or observations. We do not give time series for parents to observe it in depth. Future studies need to assess changes in social behaviour based on parental observations at one time. Furthermore, data on changes in social behaviour in children will be more detailed if done using a qualitative method. Further researchers can conduct in-depth interviews with parents. Interviews with teachers also need to be conducted as education professionals who design children's learning activities. One of the meaningful questions that further researchers can do is whether during the home-learning program, the teacher designs activities that stimulate children's social-emotional development.

\section{CONCLUSION}

The only factor that causes children's low social behaviour during the pandemic is limited interaction with other people. The findings of this study have implications for parents globally who are caring for early childhood during the pandemic and are the subjects who accompany children to play. They must continue to support children in social interactions even if only with the closest neighbours so that children remain social individuals. Children should continue to interact with peers in the house while still paying attention to health protocols. Furthermore, parents can build positive interactions by playing motor games, arts and crafts, and listening to music (Goldschmidt, 2020) or watching a movie together to minimize the decline in children's social behaviour. Attitudes and behaviour of parents who are also a factor in changing children's behaviour must be considered. Parents must allocate their time, energy, and thoughts to work and accompany their children to study at home. 


\section{REFERENCES}

Aksoy, P., \& Baran, G. (2010). Review of studies aimed at bringing social skills for children in preschool period. Procedia - Social and Behavioural Sciences, 9, 663669. https://doi.org/10.1016/j.sbspro.2010.12.214

Al-Tammemi, A. B. (2020). The Battle Against COVID-19 in Jordan: An Early Overview of the Jordanian Experience. Frontiers in Public Health, 8(May), 1-6. https://doi.org/10.3389/fpubh.2020.00188

Arkorful, V., \& Abaidoo, N. (2015). The role of e-learning, advantages, and disadvantages of its adoption in higher education. International Journal of Instructional Technology and Distance Learning, 12(1), 29-42.

Atiles, J. T., Almodóvar, M., Chavarría Vargas, A., Dias, M. J. A., \& Zúñiga León, I. M. (2021). International responses to COVID-19: Challenges faced by early childhood professionals. European Early Childhood Education Research Journal, 29(1), 66-78. https://doi.org/10.1080/1350293X.2021.1872674

Baloran, E. T. (2020). Knowledge, Attitudes, Anxiety, and Coping Strategies of Students during COVID-19 Pandemic. Journal of Loss and Trauma, 25(8), 635-642. https://doi.org/10.1080/15325024.2020.1769300

Berns, R. M. (2007). Child, Family, School, and Community. Cengage.

Brooks, S. K., Webster, R. K., Smith, L. E., Woodland, L., Wessely, S., Greenberg, N., \& Rubin, G. J. (2020). The psychological impact of quarantine and how to reduce it: Rapid review of the evidence. The Lancet, 395(10227), 912-920. https://doi.org/10.1016/S0140-6736(20)30460-8

Cachón-Zagalaz, J., Zagalaz-Sánchez, M. L., Arufe-Giráldez, V., Sanmiguel-Rodríguez, A., \& González-Valero, G. (2021). Physical activity and daily routine among children aged 0-12 during the COVID-19 pandemic in Spain. International Journal of Environmental Research and Public Health, 18(2), 1-13. https://doi.org/10.3390/ijerph18020703 
Ceylan, S. S., Erdoğan, Ç., \& Turan, T. (2021). Investigation of the effects of restrictions applied on children during Covid-19 pandemic. Journal of Pediatric Nursing, 61, 340-345. https://doi.org/10.1016/j.pedn.2021.09.013

Chaelin, K. R. et al. (2018). Association of Digital Media Use with Subsequent Symptoms of Attention Defi-cit/Hyperactivity Disorder Among Adolescents. J. Am. Med. Assoc.

Corredor, G. A., Justicia-Arráez, A., Romero-López, M., \& Benavides-Nieto, A. (2017). Longitudinal Study of the Effects of Social Competence on Behavioral Problems. Procedia - Social and Behavioral Sciences, 237(June 2016), 479-485. https://doi.org/10.1016/j.sbspro.2017.02.093

de Figueiredo, C. S., Sandre, P. C., Portugal, L. C. L., Mázala-de-Oliveira, T., da Silva Chagas, L., Raony, Í., Ferreira, E. S., Giestal-de-Araujo, E., dos Santos, A. A., \& Bomfim, P. O. S. (2021). COVID-19 pandemic impact on children and adolescents' mental health: Biological, environmental, and social factors. Progress in Neuro-Psychopharmacology and Biological Psychiatry, 106(November 2020). https://doi.org/10.1016/j.pnpbp.2020.110171

Diesendruck, G., \& Ben-Eliyahu, A. (2006). The relationships among social cognition, peer acceptance, and social behavior in Israeli kindergarteners. International Journal of Behavioral Development, 30(2), 137-147. https://doi.org/10.1177/0165025406063628

Dong, C., Cao, S., \& Li, H. (2020). Young children's online learning during COVID-19 pandemic: Chinese parents' beliefs and attitudes. Children and Youth Services Review, 118(September), 105440. https://doi.org/10.1016/j.childyouth.2020.105440

Gay, L. R., Mills, G. E., \& Airasian, P. W. (2012). Educational research: Competencies for analysis and applications (10th ed). Pearson. 
Gelir, I., \& Duzen, N. (2021). Children's changing behaviours and routines, challenges, and opportunities for parents during the COVID-19 pandemic. Education 3-13, O(0), 1-11. https://doi.org/10.1080/03004279.2021.1921822

Goldschmidt, K. (2020). The COVID-19 Pandemic: Technology use to Support the Wellbeing of Children. Journal of Pediatric Nursing, 53(xxxx), 88-90. https://doi.org/10.1016/j.pedn.2020.04.013

Goodman, A., Joshi, H., \& Nasim, B. (2015). Social and emotional skills in childhood and their long-term effects on adult life. A Review for The Eraly Intervention Foundation, March, 118.

Grier, L. K., \& Boutakidis, I. (2018). The ecology of social support in relation to academic and behavioral self-perceptions among African American boys and girls. Journal of Human Behaviour in The Social Environment, 28(6), 798-816.

Gülay, H., \& Önder, A. (2013). A study of social-emotional adjustment levels of preschool children in relation to peer relationships. Education 3-13, 41(5), 514522. https://doi.org/10.1080/03004279.2011.609827

Hu, B. Y., Johnson, G. K., Teo, T., \& Wu, Z. (2020). Relationship Between Screen Time and Chinese Children's Cognitive and Social Development. Journal of Research in Childhood Education, $\quad 34(2), \quad 183-207$. https://doi.org/10.1080/02568543.2019.1702600

Idoiaga Mondragon, N., Berasategi Sancho, N., Dosil Santamaria, M., \& Eiguren Munitis, A. (2021). Struggling to breathe: A qualitative study of children's wellbeing during lockdown in Spain. Psychology and Health, 36(2), 179-194. https://doi.org/10.1080/08870446.2020.1804570

Izza, H. (2020). Meningkatkan Perkembangan Sosial Anak Usia Dini melalui Metode Proyek. Jurnal Obsesi: Jurnal Pendidikan Anak Usia Dini, 4(2), 951. https://doi.org/10.31004/obsesi.v4i2.483 
Koh, W. C., Naing, L., \& Wong, J. (2020). Estimating the impact of physical distancing measures in containing COVID-19: An empirical analysis. International Journal of Infectious Diseases, 100, 42-49. https://doi.org/10.1016/j.ijid.2020.08.026

Kusuma, L., Dimyati, \& Harun. (2022). Perhatian Orang tua dalam Mendukung Keterampilan Sosial Anak selama Pandemi Covid-19. Jurnal Obsesi: Jurnal Pendidikan Anak Usia Dini, 6(1), 473-491. https://doi.org/10.31004/obsesi.v6i1.959

Kyriazis, A., Mews, G., Belpaire, E., Aerts, J., \& Malik, S. A. (2020). Physical distancing, children, and urban health. Cities \& Health, O0(00), 1-6. https://doi.org/10.1080/23748834.2020.1809787

Lau, E. Y. H., \& Lee, K. (2020). Parents' Views on Young Children's Distance Learning and Screen Time During COVID-19 Class Suspension in Hong Kong. Early Education and Development, OO(00), 1-18. https://doi.org/10.1080/10409289.2020.1843925

Leeuw, R. A. De, Logger, D. N., Westerman, M., Bretschneider, J., Plomp, M., \& Scheele, F. (2019). Influencing factors in the implementation of postgraduate medical e-learning: A thematic analysis. 1-10.

Liu, Y., Yue, S., Hu, X., Zhu, J., Wu, Z., Wang, J., \& Wu, Y. (2021). Associations between feelings/behaviors during COVID-19 pandemic lockdown and depression/anxiety after lockdown in a sample of Chinese children and adolescents. Journal of Affective Disorders, 284(November 2020), 98-103. https://doi.org/10.1016/j.jad.2021.02.001

Mantovani, S., Bove, C., Ferri, P., Manzoni, P., Cesa Bianchi, A., \& Picca, M. (2021). Children 'under lockdown': Voices, experiences, and resources during and after the COVID-19 emergency. Insights from a survey with children and families in the Lombardy region of Italy. European Early Childhood Education Research Journal, 29(1), 35-50. https://doi.org/10.1080/1350293X.2021.1872673 
McCormack, G. R., Doyle-Baker, P. K., Petersen, J. A., \& Ghoneim, D. (2020). Parent anxiety and perceptions of their child's physical activity and sedentary behaviour during the COVID-19 pandemic in Canada. Preventive Medicine Reports, 20, 101275. https://doi.org/10.1016/j.pmedr.2020.101275

Melinda, A. E., \& Izzati. (2014). Perkembangan Sosial Anak Usia Dini. Jurnal Pendidikan Anak Usia Dini Undiksha, 9(1), 127-131.

Merell, K. W. (2013). Prechool and kindergarten behavior scales. In Journal of Chemical Information and Modeling (Vol. 53, Issue 9).

Merkaš, M., Perić, K., \& Žulec, A. (2021). Parent Distraction with Technology and Child Social Competence during the COVID-19 Pandemic: The Role of Parental Emotional Stability. Journal of Family Communication, 21(3), 186-204. https://doi.org/10.1080/15267431.2021.1931228

Mochida, S., Sanada, M., Shao, Q., Lee, J., Takaoka, J., Ando, S., \& Sakakihara, Y. (2021). Factors modifying children's stress during the COVID-19 pandemic in Japan. European Early Childhood Education Research Journal. https://doi.org/10.1080/1350293X.2021.1872669

Mohamed, A. H. H. (2017). Gender as a moderator of the association between teacher child relationship and social skills in preschool. Early Child Development and Care, O(0), 1-15. https://doi.org/10.1080/03004430.2016.1278371

Morelli, M., Cattelino, E., Baiocco, R., Trumello, C., Babore, A., Candelori, C., \& Chirumbolo, A. (2020). Parents and Children During the COVID-19 Lockdown: The Influence of Parenting Distress and Parenting Self-Efficacy on Children's Emotional Well-Being. Frontiers in Psychology, 11(October), 1-10. https://doi.org/10.3389/fpsyg.2020.584645

Morgül, E., Kallitsoglou, A., \& Essau, C. (2020). Psychological effects of the COVID19 lockdown on children and families in the UK. Revista de Psicología Clínica Con Niños $\quad y \quad$ Adolescentes, $\quad 7(3), \quad 42-48$. https://doi.org/10.21134/rpcna.2020.mon.2049 
Munasinghe, S., Sperandei, S., Freebairn, L., Conroy, E., Jani, H., Marjanovic, S., \& Page, A. (2020). The Impact of Physical Distancing Policies During the COVID19 Pandemic on Health and Well-Being Among Australian Adolescents. Journal of Adolescent Health, 67(5), 653-661. https://doi.org/10.1016/j.jadohealth.2020.08.008

Munastiwi, E., \& Puryono, S. (2021). Unprepared management decreases education performance in kindergartens during Covid-19 pandemic. Heliyon, 7(5), e07138. https://doi.org/10.1016/j.heliyon.2021.e07138

Naser, A. Y., Al-Hadithi, H. T., Dahmash, E. Z., Alwafi, H., Alwan, S. S., \& Abdullah, Z. A. (2020). The effect of the 2019 coronavirus disease outbreak on social relationships: A cross-sectional study in Jordan. International Journal of Social Psychiatry. https://doi.org/10.1177/0020764020966631

Nofziger, S. (2008). The "Cause" of Low Self-Control. Journal Research in Crime and Delinquency, 45(2), 191-224.

O'Keeffe, C., \& McNally, S. (2021). 'Uncharted territory': Teachers' perspectives on play in early childhood classrooms in Ireland during the pandemic. European Early Childhood Education Research Journal, 29(1), 79-95. https://doi.org/10.1080/1350293X.2021.1872668

Ozturk Eyimaya, A., \& Yalçin Irmak, A. (2021). Relationship between parenting practices and children's screen time during the COVID-19 Pandemic in Turkey. Journal of Pediatric Nursing, 24-29. https://doi.org/10.1016/j.pedn.2020.10.002

Parczewska, T. (2020). Difficult situations and ways of coping with them in the experiences of parents homeschooling their children during the COVID-19 pandemic in Poland. Education 3-13, O(0), 1-12. https://doi.org/10.1080/03004279.2020.1812689

Pascal, C., \& Bertram, T. (2021). What do young children have to say? Recognising their voices, wisdom, agency and need for companionship during the COVID 
pandemic. European Early Childhood Education Research Journal, 20-34. https://doi.org/10.1080/1350293X.2021.1872676

Popyk, A. (2020). The impact of distance learning on the social practices of schoolchildren during the COVID-19 pandemic: Reconstructing values of migrant children in Poland. European Societies, O(0), 1-15. https://doi.org/10.1080/14616696.2020.1831038

Quennerstedt, A. (2016). Young children's enactments of human rights in early childhood education. International Journal of Early Years Education, 24(1), 5-18. https://doi.org/10.1080/09669760.2015.1096238

Rachman, S. P. D., \& Cahyani, I. (2019). Perkembangan Keterampilan Sosial Anak Usia Dini. (JAPRA) Jurnal Pendidikan Raudhatul Athfal (JAPRA), 2(1), 52-65. https://doi.org/10.15575/japra.v2i1.5312

Ramadhani, P. R., \& Fauziah, P. Y. (2020). Hubungan Sebaya dan Permainan Tradisional pada Keterampilan Sosial dan Emosional Anak Usia Dini Abstrak. Jurnal Obsesi : Jurnal Pendidikan Anak Usia Dini, 4(2), 1011-1020. https://doi.org/10.31004/obsesi.v4i2.502

Ren, L., Hu, B. Y., \& Song, Z. (2019). Child routines mediate the relationship between parenting and social-emotional development in Chinese children. Children and Youth Services Review, 98(December 2018), 1-9. https://doi.org/10.1016/j.childyouth.2018.12.016

Ren, L., \& Xu, W. (2019). Coparenting and Chinese preschoolers' social-emotional development: Child routines as a mediator. Children and Youth Services Review, 107, 104549. https://doi.org/10.1016/j.childyouth.2019.104549

Rusmayadi, \& Herman. (2019). The Effect of Social Skill on Children's Independence. Journal of Educational Science and Technology, 5(2), 159-165.

Sari, C. R., Hartati, S., \& Yetti, E. (2019). Peningkatan Perilaku Sosial Anak melalui Permainan Tradisional Sumatera Barat. Jurnal Obsesi: Jurnal Pendidikan Anak Usia Dini, 3(2), 416-424. https://doi.org/10.31004/obsesi.v3i2.225 
Sendil, C. O., \& Erden, F. T. (2012). Preschool Teachers' Strategies to Enhance Social Interaction Skills of Children during Playtime. Procedia - Social and Behavioral Sciences, 47, 918-923. https://doi.org/10.1016/j.sbspro.2012.06.757

Setiawati, E., Solihatulmillah, E., Cahyono, H., \& Dewi, A. (2019). The Effect of Gadget on Children's Social Capability. Journal of Physics: Conference Series, 1179(1). https://doi.org/10.1088/1742-6596/1179/1/012113

Setyawan, C. F., Sudirman, D. F., Sari, D. P., Rizki, F., Eva, N., Psi, S., \& Psi, M. (2021). Asesmen Perkembangan Sosio Emosinal pada Anak Usia Dini. Prosiding Seminar Nasional Dan Call Paper Mahasiswa "Memperkuat Kontribusi Kesehatan Mental Dalam Penyelesaian Pandemi Covid 19: Tinjauan Multidisipliner”, April, 58-70.

Sheridan, S. M., Knoche, L. L., Boise, C., Witte, A., Koziol, N., Prokasky, A., Schumacher, R., \& Kerby, H. (2021). Relationships as Malleable Factors for Children's Social-Behavioral Skills from Preschool to Grade 1: A Longitudinal Analysis. Early Education and Development, O0(00), 1-21. https://doi.org/10.1080/10409289.2021.1936374

Siekkinen, M., Pakarinen, E., Lerkkanen, M., Poikkeus, A., Salminen, J., Poskiparta, E., \& Nurmi, E. (2014). Early Education and Development Social Competence Among 6-year-old Children and Classroom Instructional Support and Teacher Stress. Early Education and Development, 24(6), 877-897. https://doi.org/10.1080/10409289.2013.745183

Sintia, N., Kuswanto, C. W., \& Meriyati, M. (2019). Meningkatkan Kemampuan Sosial Anak Usia Dini dengan Model Outbound. Jurnal CARE (Children Advisory Research and Education), 6(2), 1-10.

Siregar, S. L., \& Subiyantoro. (2021). Peran Orang Tua dalam Mengembangkan Kemampuan Sosial Emosioal Anak Usia Dini. EDUKIDS: Jurnal Pertumbuhan, Perkembangan, Dan Pendidikan Anak Usia Dini, 18(1), 1-6. https://doi.org/10.17509/edukids.v18i1.31828 
Stephen, C., \& Edwards, S. (2018). Young Children Playing and Learning in a Digital Age. Routledge.

Tchimtchoua Tamo, A. R. (2020). An analysis of mother stress before and during COVID-19 pandemic: The case of China. Health Care for Women International, 41(11-12), 1-14. https://doi.org/10.1080/07399332.2020.1841194

Unnever, J. D., Cullen, F. T., \& Agnew, R. (2006). Why is "Bad" Parenting Criminogenic? Implications From Rival Theories. Youth Violence and Juvenile Justice, 4(1), 3-33. https://doi.org/10.1177/1541204005282310

Wang, S., Hu, B. Y., LoCasale-Crouch, J., \& Li, J. (2021). Supportive parenting and social and behavioral development: Do classroom emotional support moderate? Journal of Applied Developmental Psychology, 77(101331).

Zhang, X. (2021). Barriers and benefits of primary caregivers' involvement in children's education during COVID-19 school closures. International Journal of Disaster $\begin{array}{lll}\text { Risk } \quad \text { Reduction, } & \text { 66(December } & \text { 2020), }\end{array}$ https://doi.org/10.1016/j.ijdrr.2021.102570

Zhang, X., \& Nurmi, J. E. (2012). Teacher-child relationships and social competence: A two-year longitudinal study of Chinese preschoolers. Journal of Applied Developmental Psychology, 33(3),

$125-135$. https://doi.org/10.1016/j.appdev.2012.03.001 